\title{
Restraining Inflation
}

NFLATION continues to be a major concern of consumers, producers and stabilization policymakers. The strong desire to reduce the rate of inflation is apparently tempered by an equally strong desire to avoid a sharp reduction in the growth of real product and employment. Economic analysts are looking for signs that restraint is being effectively pursued by monetary and fiscal means and that the growth of total demand is moderating. At the same time we are cautioned that too rapid a slowdown in the growth of total spending could have serious repercussions on the rate of growth of production and employment.

\section{Total Spending}

Total demand for goods and services has continued to rise at a pace exceeding the growth of the productive capability of the economy, despite some slowing in the growth of total spending since mid-1968. From the third to the fourth quarter last year total spending, as measured by Gross National Product, increased at a 7.8 per cent annual rate, less than the 9.5 per cent growth in the previous four quarters, but the same as the average rate for the previous three inflationary years.

The rapid 9 per cent rate of advance of total spending in 1968 characterized all major spending groups in the economy, although the relative importance of spending groups shifted from quarter to quarter. Quarterly changes in the components of total spending are summarized in Table I.

The course of consumer spending and of business spending for inventories shifted in an altemating pattern during 1968. In the first and third quarters consumer expenditures accounted for the largest portion of increases in spending, while spending for business inventories declined. In the second and fourth quar.

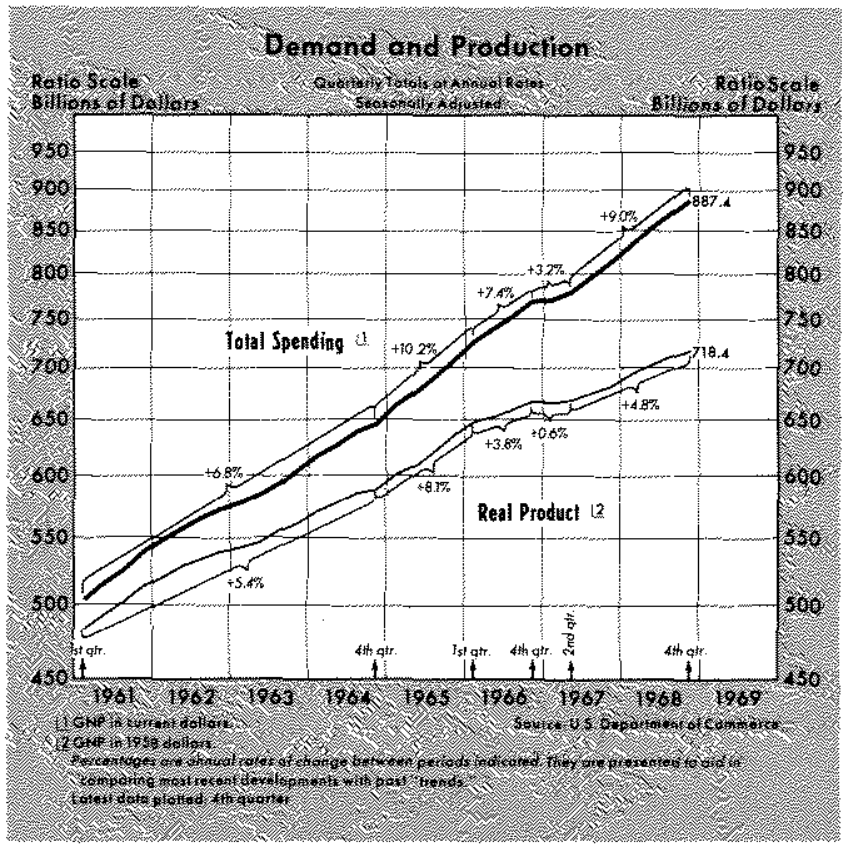

ters, when consumption spending was rising at a reduced rate, spending for business inventories increased markedly. The fourth quarter slowing in consumer spending has been attributed partly to the flu epidemic and to fewer shopping days between Thanksgiving and Christmas than usual.

The level of retail sales increased only slightly on balance from September to February, after increasing $\$ 1.9$ billion from January 1968 to September, or at a 10.5 per cent annual rate. A slowing in the rate of increase of income may have been a factor in the leveling of consumer spending in the past six months. From last September to January, personal income rose at a 6.8 per cent annual rate, compared with a 9.8 per cent rate in the previous year. From December to Jamuary, personal income increased at less than a 3 per cent annual rate because of the in -

Toble I

CHANGES IN COMPOINENTS OF TOTAI SPENDING, 1968 ?

(onnuol rates of elonge in porentheses)

Q $00 \mathrm{smphom}$

red Inventmen

$410 n g 0 \%$ n Busness hrontortes

Govi spending

Net Exports

$101015 \mathrm{pend} 1 \mathrm{~g}$

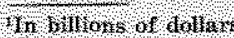

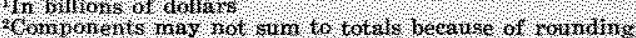

Ist Quorter

172,14,

$4,1,3$

6.2

1,0162

10

20210.4

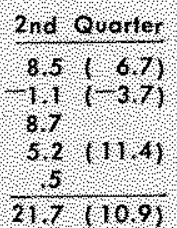

$4 \mathrm{~h}$ Quater

$5,14,31$

$6.4,23,2$

31

3.4 10

33

164178
4

101801 
crease in social security taxes and other special factors such as strikes in the shipping and petroleum industries. However, in February personal income probably increased at about the same rate as the average rates of increase since last July. From the third to the fourth quarter 1968, disposable income increased at a 6.7 per cent rate, compared with a 7.8 per cent average increase in the previous four quarters.

The rate of increase of fixed investment, including spending for plant and equipment and residential construction, rose sharply from the third to the fourth quarter of 1968, and the economy continues to operate at a high level of labor and other resource utilization. Even so, production has continued to advance rapidly. From September 1968 to January 1969, industrial production increased at an 8 per cent rate, compared with a 5.3 per cent rate in the previous twelve months.

\section{Real Product, Prices and Employment}

The increase in total spending from late 1967 to late 1968 was manifested in a 5.4 per cent increase in real output and a 3.9 per cent increase in the average level of prices. In the fourth quarter, growth

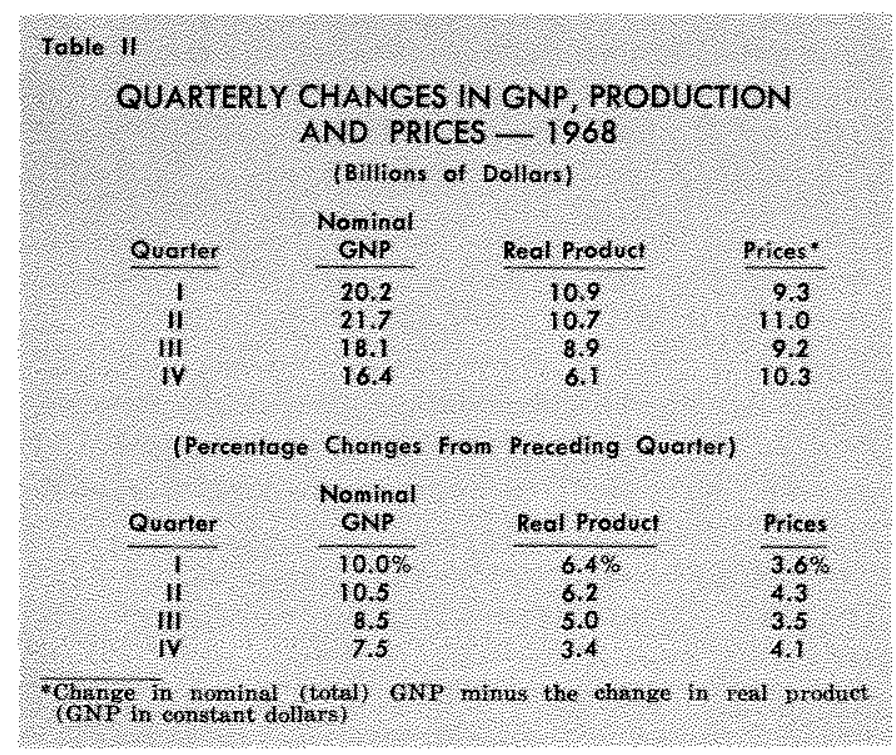

of real product slowed to a 3.5 per cent annual rate, while prices continued to rise at a 4 per cent rate. The distribution of changes in total spending between prices and real product in each of the four quarter: of 1968 is shown in Table II. Most of the slower growth of total spending in the second half of 1968 was manifested in reductions in the growth of real product. It is unlikely that the growth of real product could be maintained at rates much above 4 per cent per year for very long, because of limitations on resources such as labor, productive facilities, and technology. The very large increases in real product in the first two quarters of last year were possible because the economy was able to bring additional resources into production at higher costs.

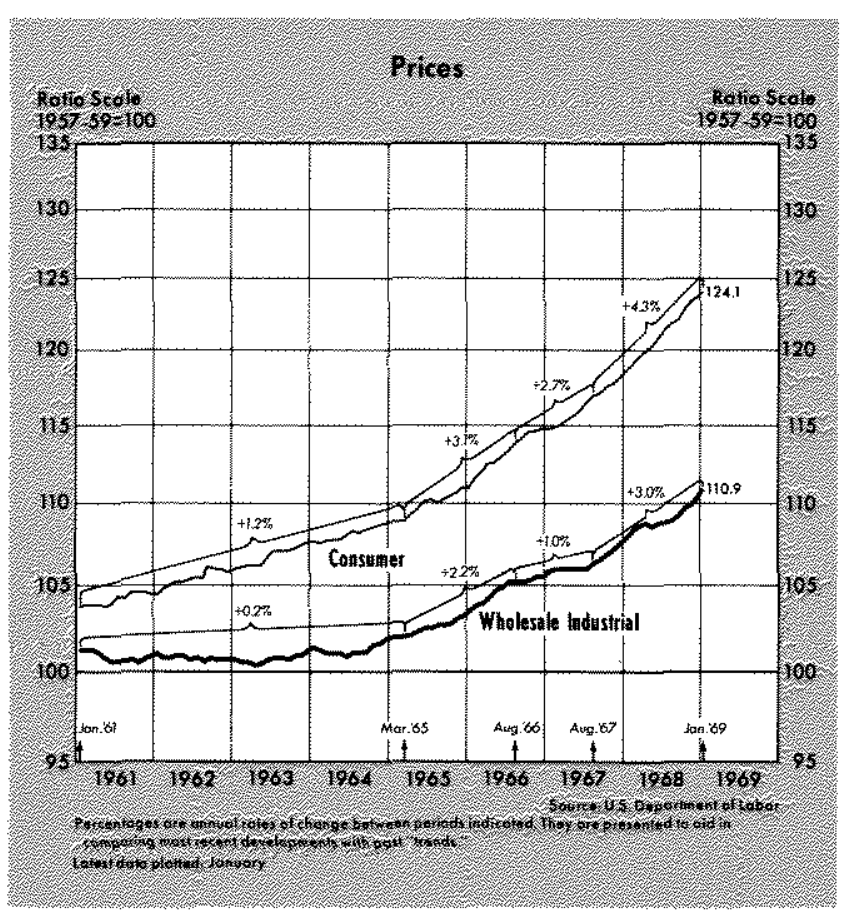

The rapid rate of price increases has continued into 1969. The consumer price index has continued to rise rapidly early this year, after accelerating from about a 4 per cent average rate in the second half of 1967 to nearly a 5 per cent average rate in the second half of 1968. Wholesale prices of industrial commodities went up at an 8 per cent rate in January after rising about 2.6 per cent in the previous year. Wholesale prices of farm products also increased at a very rapid rate in January and, as a result, wholesale prices of all commodities increased at a 10.3 per cent annual rate from December to January.

Total civilian employment increased at a rapid 7 per cent annual rate from October 1968 to February, representing an increase of almost $13 / 4$ million persons. The unemployment rate remained at 3.3 per cent of the labor force in January and February, matching December's 15-year low. Unemployment among married men was 1.4 per cent in the first two months of this quarter, compared with 2.4 per cent in 1965 . Employment as a percentage of population of working age also indicated an increase in the intensity of manpower usage last year. In 1968,73 per cent of those between the ages of 20 and 64 were employed. 


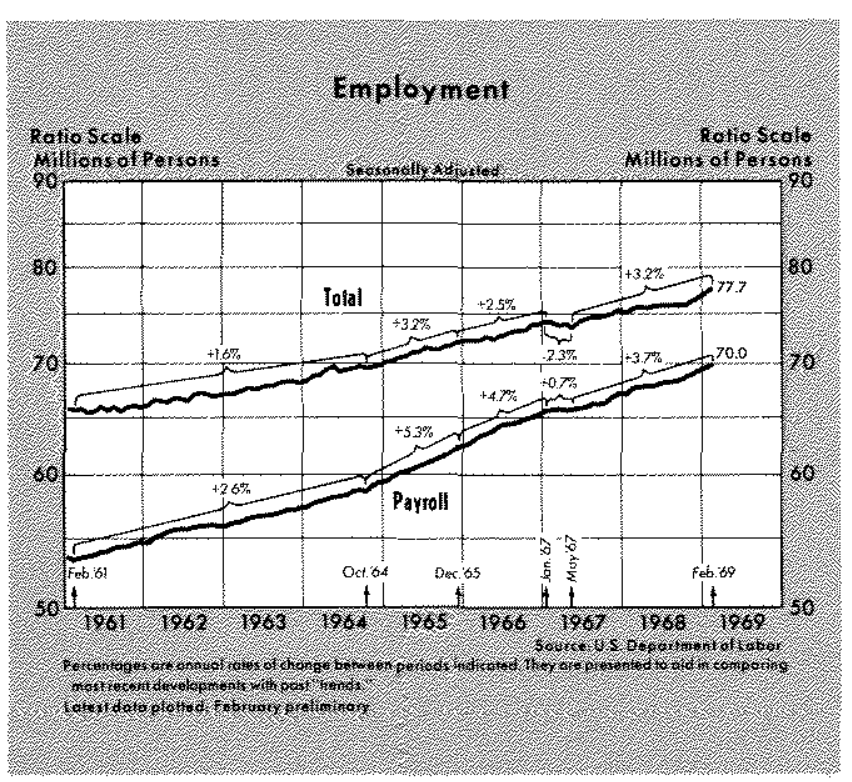

At the peak of the Korean War (1953) this ratio was 68 per cent, and when economic activity was at a high level in 1957, 1959, and 1965, the figures were 69 per cent, 69 per cent and 71,4 per cent, respectively.

Real product growth would be expected to slow to its full-employment potential rate (probably about 4 per cent) when the economy moves beyond an efficient level of resource use. This full-employment growth rate of real product can be exceeded only temporarily due to stimulative actions which attract larger amounts of resources into production, but at the cost of acceleration of inflation. Since the slowing of total spending in the third and fourth quarters of last year was matched by an unavoidable slowing of real product growth to its full employment potential, it may be inferred that the economy was subjected to a similar amount of excessive inflationary stimulus throughout last year.

\section{Credit Demand and Interest Rates}

The demand for loans has been very strong during early 1969. Business loans at large commercial banks have increased at an 18 per cent annual rate in the past three months, almost twice the 9.6 per cent trend rate from 1960 to 1968 . Banks have liquidated some securities in meeting the rising demand for loans. In recent months the loan portion of bank credit has risen sharply, while the investment portion of bank credit has declined.

Most market interest rates rose slightly in January and February after rising sharply from October to record high levels in late December. Interest rates on four- to six-month commercial paper averaged 6.75 per cent in late February, compared with 6.25 per cent in late December and 5.8 per cent in October. Yields on three-month Treasury bills declined seasonally to an average of 6.1 per cent in late February, compared with 6.2 per cent in late December and 5.35 per cent in October.

Interest rates on long-term securities have moved in a similar pattern. Yields on long-term Government bonds rose from 5.24 per cent during October to 5.82 per cent in late December. The average yield on corporate Aaa bonds rose from 6.09 per cent in $\mathrm{Oc}$ -

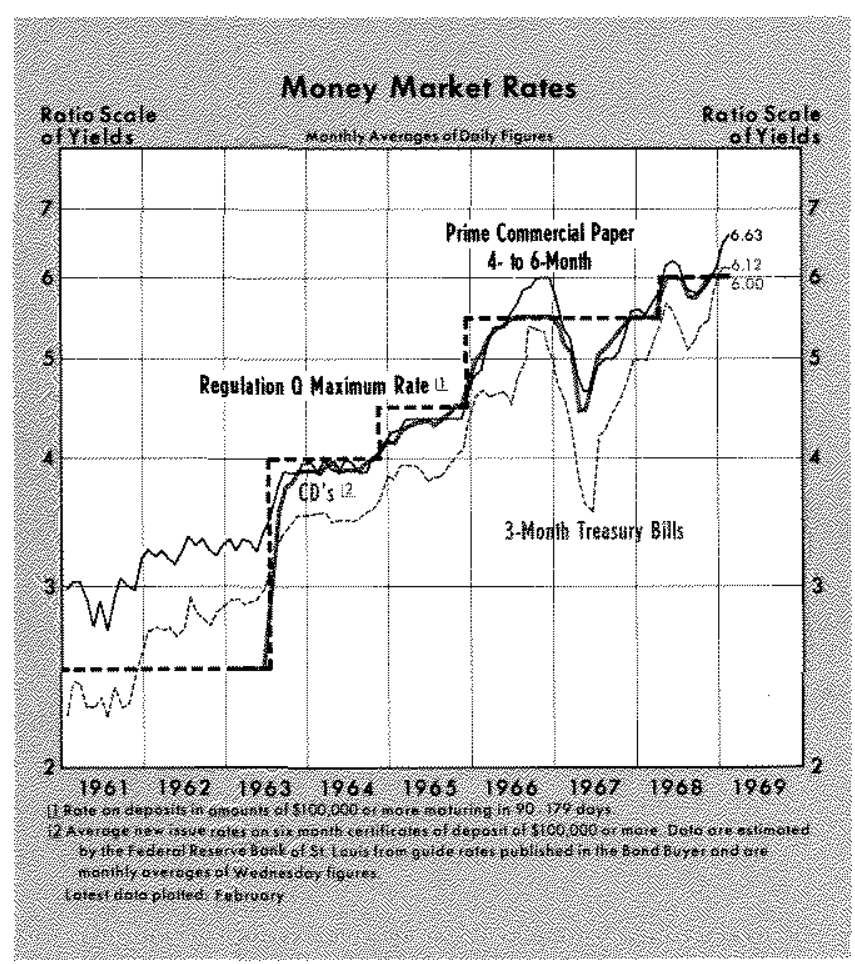

tober to 6.53 per cent in late December. During February the yields on these securities averaged 5.86 and 6.66 per cent, respectively.

The high levels of interest rates suggest to many analysts that "money has been very tight." However, if nominal interest rates are adjusted for inflationary expectations, interest rates do not indicate such a degree of tightness. Recent and anticipated inflation have altered the portfolio preferences of asset holders away from financial assets with fixed nominal yields, while encouraging spending financed through borrowing.

\section{The Money Stock and the Monetary Base}

In the past three months expansion of some monetary aggregates has slowed from the very rapid pace of the previous two years. However, part of the slow- 


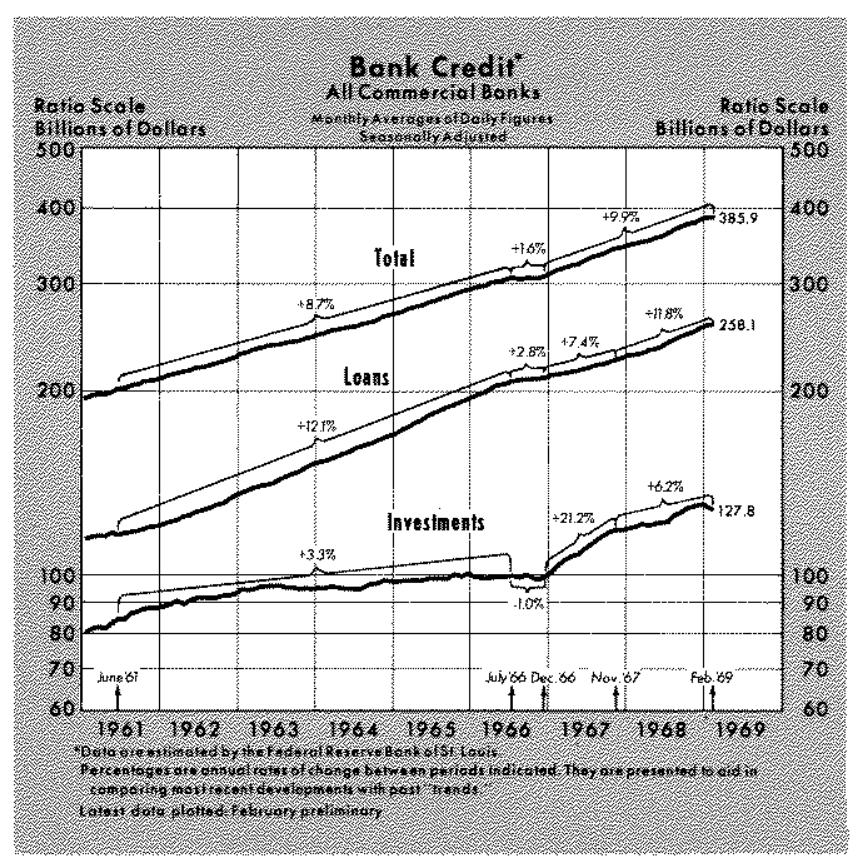

ing can be explained by special circumstances, requiring more careful interpretation of the apparent signs of restraint in some indicators, as discussed below.

The money stock, consisting of private demand deposits and currency in the hands of the public, increased at only a 4 per cent annual rate in the past three months, slower than the 6.4 per cent rate of the past two years. Analysis of the growth of money for very short periods of a few months must consider the influence of fluctuations of U.S. Government deposits at commercial banks, as pointed out in "Re-

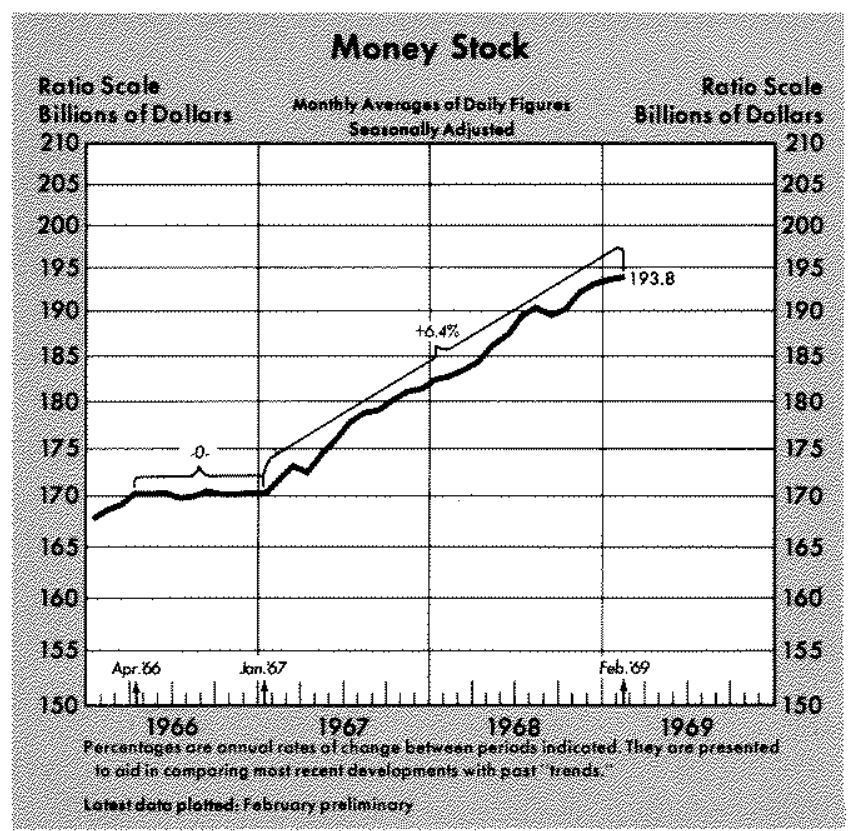

lations Among Monetary Aggregates" in this Review. From December to February there was an unusual buildup in Government deposits (not included in money) causing private deposits to be correspondingly less than they would otherwise have been for the same amounts of the monetary base. As Government deposits at commercial banks decline, private demand deposits and the money stock probably will rise rapidly if the monetary base continues to increase at the recent rapid rate.

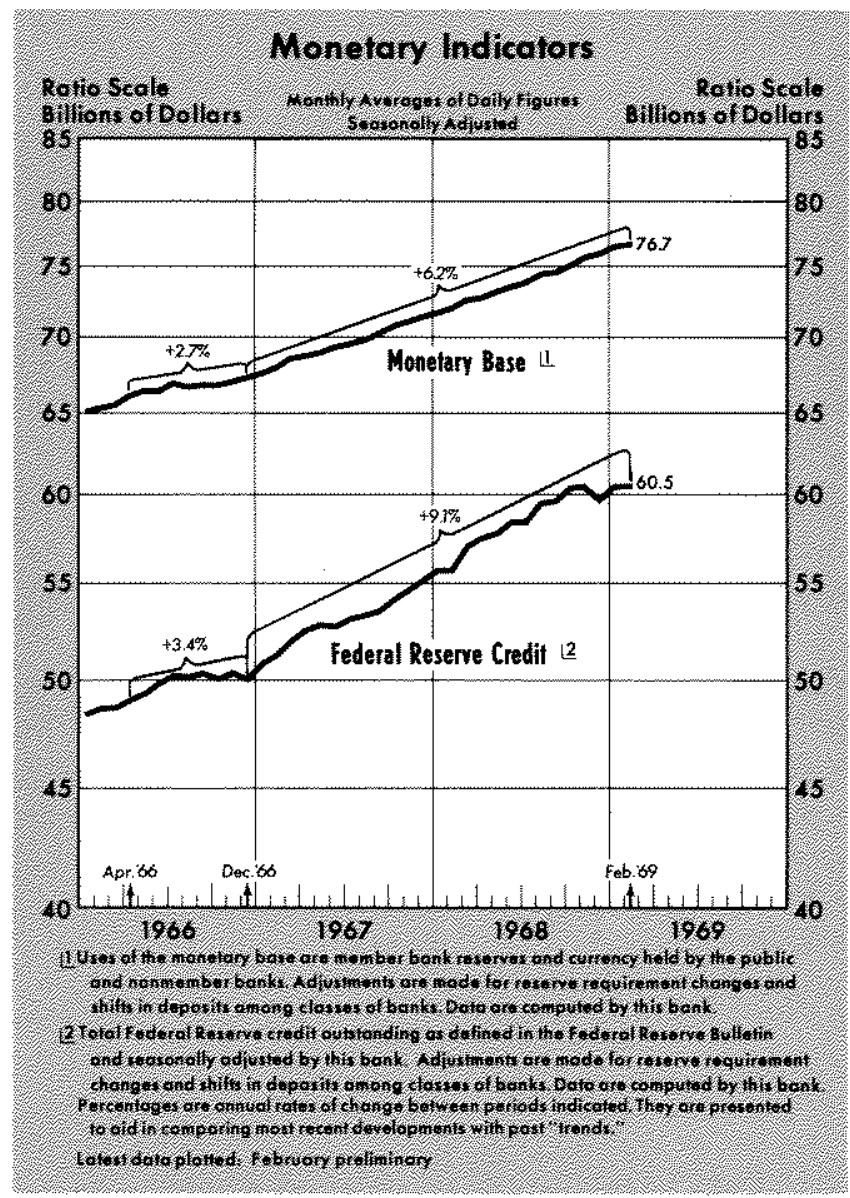

The monetary base, the total credit supplied by the Treasury and Federal Reserve to the private sector of the economy, ${ }^{1}$ has risen at a 5.4 per cent annual rate in the last three months, compared with the rapid 6.2 per cent rate of the past two years, and above the 3.6 per cent trend rate from 1957 to 1968. The growth of the monetary base dominates the trend growth of the money stock over time.

\section{Disintermediation}

Growth rates of the money stock plus time deposits and of total credit at commercial banks have slowed

1See "The Monetary Base - Explanation and Analytical Use," in the August 1968 issue of this Review. 
markedly since December. The broad measure of money decreased at a 3.9 per cent annual rate from December to February, compared with an 8.5 per cent rate of increase during the past two years. Bank credit has increased at a 2.4 per cent rate since December, compared with a 10 per cent rate of increase since late 1966.

The slowing in the growth of these two measures, money plus time deposits and bank credit, is largely the result of the disintermediation of bank time de posits caused by market interest rates rising relative to rates banks are permitted to pay on time deposits. New issue interest rates on large negotiable certificates of deposit ( $\$ 100,000$ or more) at commercial banks reached the maximums permitted under Regulation $Q$ in late November 1968, while rates on commercial paper and other market instruments continued to rise. Large certificates of deposit at large commercial banks declined from $\$ 24.3$ billion in early December to $\$ 19.6$ billion on March 5. Total time deposits at commercial banks have declined at a 9 per cent annual rate since December.

The contraction of CD's and resulting slowing in the growth of total bank deposits and bank credit have been cited by some observers as signs of significant tightening of monetary actions. Although the decline of time deposits does restrict the growth of total bank deposits and bank credit, it does not necessarily limit growth of total liquid assets or total credit in the economy. As time deposits at commercial banks decline, funds are made available in the market through other credit instruments. Total deposits and, therefore, total assets of commercial banks decline, but the restriction of bank credit growth caused by the interest rate ceilings on time deposits is probably not any greater than the offsetting increased growth of credit in nonregulated markets.

As discussed in "Relations Among Monetary Aggregates" in this Review, the falling demand for time deposits, caused by high market interest rates relative to Regulation $Q$ cellings, is the cause of the decline in the growth of money plus time deposits and bank credit. Therefore, the observed slower growth of these two aggregates is not sufficient information to indicate that monetary actions have become less stimulative since November.

The rise in the volume of net borrowed reserves has also been cited as an indication of monetary restraint. Borrowings from Federal Reserve Banks averaged $\$ 820$ million during February, up from $\$ 570$ million in November. Other sources of funds to banks have been relatively expensive, as interest rates on Federal Funds and short-term assets remain high compared to the discount rate, and banks continue to lose large CD's. During February, the three-month Treasury bill rate averaged 60 basis points above the discount rate. On average since 1961 , the bill rate has been slightly below the discount rate. The increased borrowing probably refects a decline in banks' liquidity, and has contributed to bank reserves and continued money creation.

\section{Summary}

Total demand for goods and services remains excessive; therefore, upward pressures on prices continue to be intense. The major short-run domestic economic objective is to reduce the excessive total spending, and hence inflationary pressures, without causing an undue interruption in the growth of production. While the slight reduction in the growth rate of total spending from the second to fourth quarters in 1968 was manifested in a deceleration of the growth in real product, employment and production in early 1969 continue to show exceptional strength. The general level of prices rose at a 4 per cent rate throughout last year, and the increases in consumer and wholesale prices have continued into early 1969 .

Monetary authorities recently have announced intentions to impose monetary restraints on economic activity in order to reduce the intensity of the inflation. Since monetary actions affect spending with a delayed effect over time, monetary actions must be judged by proximate measures. The measures commonly used, if not properly interpreted, currently give contradictory signals. Recent slower growth rates of money, money plus time deposits, and bank credit, or high market rates of interest and a large volume of net borrowed reserves, have led some observers to conclude that monetary actions in recent months have been highly restrictive. However, others note that the monetary base has continued to increase rapidly, that the slower growth of money was chiefly the result of a large and temporary buildup of U.S. Government deposits at commercial banks, and that the slower growth of both money plus time deposits and bank credit was the result of Regulation $Q$ interest rate ceilings and does not indicate any reduction in total credit flows. Thus interpreted, available data seem to indicate that lasting monetary restraint may not yet have been exercised. The observed slower rates of monetary expansion will only be effective if they are maintained over the next few months. 